\title{
High Ventilatory Response to Hypoxia Observed in Obese Judo Athletes
}

\author{
Yoshio Ohyabu, * Akio Yoshida, * Fumiaki Hayashi, \\ Nobuyuki SATo,** and Yoshiyuki HondA* \\ *Department of Physiology, School of Medicine, \\ Chiba University, Chiba, 280 Japan \\ **School of Physical Education, Tokai \\ University, Hiratsuka, Kanagawa, 259-12 Japan
}

\begin{abstract}
Fifty-two active Judo athletes were examined using an isocapnic progressive hypoxia test. The results were analyzed by the hyperbola ventilation equation $\dot{V}=\dot{V}_{\mathrm{O}}+A /\left(P_{\mathrm{ET}_{\mathrm{O}_{2}}}-C\right)$, where $\dot{V}$ is observed ventilation, $\dot{V}_{\mathrm{O}}$ the horizontal asymptote in ventilation for infinite end-tidal $P_{\mathrm{O}_{2}}\left(P_{\mathrm{ET}_{\mathrm{O}_{2}}}\right), A$ the slope constant indicating magnitude of hypoxic sensitivity, and $C$ the vertical asymptote in $P_{\mathrm{ET}_{\mathrm{O}_{2}}}$ for infinite ventilation.

Hypoxic sensitivity, $A$, was positively correlated with body weight (BW). Such correlation in the light and middleweight groups $(B W<95 \mathrm{~kg})$ and the heavyweight group (BW $>95 \mathrm{~kg}$ ) with Röhrer's index being less than 200 became insignificant when the $A$ value was recalculated after normalization of ventilation for $70 \mathrm{~kg}$ body mass. However, the heavyweight group with a Röhrer index of higher than 200 still exhibited a significantly higher $A$ value than the light and middleweight groups after normalization of ventilation. These results indicated that body weight plus obesity were determining factors in the increase of hypoxic sensitivity in our subjects.

Key Words: progressive hypoxia, ventilation, Judo athlete, obesity.
\end{abstract}

Obesity is known to often be accompanied by hypoventilation, somnolence, hypoxemia, and/or hypercapnia, symptoms collectively called "Pickwickian syndrome" (BuRWell et al., 1956). Decreased ventilatory or respiratory motor responses to hypoxia and $\mathrm{CO}_{2}$ have also been verified in patients suffering from this syndrome (Cullen and Formel, 1962; Lourenço, 1969; Zwillich et al., 1975a; KronenBERG et al., 1977; GARAY et al., 1981). However, in 1975 Kronenberg et al. demonstrated that inpairments in these respiratory functions are not invariably associated with obesity. In the present study, we found an increased instead of a decreased ventilatory response to hypoxia in obese Judo athletes who were in excellent health with severe training conducted daily.

Received for publication February 23, 1982

大藪由夫，吉田明夫，林 文明，佐藤宣践，本田良行 


\section{MATERIALS AND METHODS}

Subjects. Fifty-two male subjects ranging from 17 to 23 years of age were studied. They were all physically active and participating in at least $3 \mathrm{hr}$ training every day except Sunday. Informed consent was obtained from all the subjects upon explanation of the experimental design. Subjects weighing less than and over $95 \mathrm{~kg}$ were designated as being of light and middleweight class and heavyweight classes, respectively. The latter was further divided on the basis of Röhrer's index (RI) expressing degree of obesity: Groups A and B were up to and above RI 200, respectively. Mean values of the physical characteristics and the pulmonary functions of the above three groups are shown in Table 1. In general, all the subjects were above normal as regards physical characteristics of the Japanese, and were in excellent health. They had been trained for about 8-10 yrs. In all three groups, both per cent vital capacity $(\% \mathrm{VC})$ and per cent forced expiratory volume in one second $\left(\mathrm{FE} V_{1} \%\right)$ were well in the range of normal values,

Table 1. Physical characteristics, pulmonary functions and ventilatory responses to hypoxia of the subjects.

\begin{tabular}{|c|c|c|c|}
\hline & \multirow{2}{*}{$\begin{array}{c}\text { Group I } \\
\text { Light and } \\
\text { middleweight } \\
\text { class } \\
(\mathrm{BW}<95 \mathrm{~kg})\end{array}$} & \multicolumn{2}{|c|}{$\begin{array}{c}\text { Group II } \\
\text { Heavyweight class (BW>95 kg) }\end{array}$} \\
\hline & & $\mathrm{A}(\mathrm{RI}<200)$ & $\mathrm{B}(\mathrm{RI}>200)$ \\
\hline$N$ & 35 & 11 & 6 \\
\hline \multicolumn{4}{|l|}{ Physical characteristics: } \\
\hline Height $(\mathrm{cm})$ & $172 \pm 6$ & $180 \pm 3$ & $175 \pm 5$ \\
\hline Weight (kg) & $76 \pm 9$ & $105 \pm 7$ & $116 \pm 10$ \\
\hline Röhrer's index & $149 \pm 13$ & $181 \pm 13$ & $215 \pm 9$ \\
\hline Age & $20 \pm 1$ & $20 \pm 1$ & $21 \pm 1$ \\
\hline Training period (yrs) & $8 \pm 1$ & $8 \pm 1$ & $10 \pm 1$ \\
\hline \multicolumn{4}{|l|}{ Pulmonary functions: } \\
\hline$\% \mathrm{VC}$ & $109 \pm 11$ & $10.8 \pm 13$ & $110 \pm 16$ \\
\hline FEV $_{1} \%$ & $85 \pm 7$ & $85 \pm 7$ & $87 \pm 6$ \\
\hline \multicolumn{4}{|l|}{ Ventilatory responses to hypoxia: } \\
\hline$A$ (liters $\left.\cdot \min ^{-1} \cdot \mathrm{mmHg}\right)$ & $295 \pm 264$ & $458 \pm 323^{*}$ & $1,155 \pm 1,027^{* * *}$ \\
\hline$A_{\mathrm{N}}\left(\right.$ liters $\left.\cdot \min ^{-1} \cdot \mathrm{mmHg}\right)$ & $271 \pm 220$ & $333 \pm 224$ & $770 \pm 657 * *$ \\
\hline$C(\mathrm{mmHg})$ & $30 \pm 6$ & $29 \pm 10$ & $24 \pm 14$ \\
\hline Aa (liters $\left.\cdot \mathrm{min}^{-1} \cdot \mathrm{mmHg}\right)$ & $278 \pm 249$ & $431 \pm 304^{*}$ & $1,087 \pm 966^{* * *}$ \\
\hline$A_{\mathrm{N}} \mathrm{a}\left(\right.$ liters $\left.\cdot \mathrm{min}^{-1} \cdot \mathrm{mmHg}\right)$ & $255 \pm 207$ & $313 \pm 210$ & $725 \pm 618^{* *}$ \\
\hline $\mathrm{Ca}(\mathrm{mmHg})$ & $24 \pm 6$ & $23 \pm 10$ & $18 \pm 13$ \\
\hline
\end{tabular}

Values are mean \pm S.D. BW: body weight. RI: Röhrer's index. \%VC: per cent vital capacity. $\mathrm{FEV}_{1} \%$ : per cent forced vital capacity in one second. $A$ : slope index of hypoxic ventilatory response curve in the hyperbola equation. $A_{\mathrm{N}}$ : normalized $A$ for $70 \mathrm{~kg}$ body mass. $C$ : asymptote for end-tidal $P_{\mathrm{O}_{2}}$ in the hyperbola equation. Suffix a for $A, A_{\mathrm{N}}$ and $C$ indicates that analysis for hypoxic response is conducted in terms of arterial $P_{\mathrm{O}_{2}}$.

$* * *$ and $* *$ differences between Group I and II B are significant at 0.1 and $1 \%$ levels, repectively.

* difference between Group II A and B is significant at $5 \%$ level. 
and no significant differences were seen between the respective groups.

Experimental procedure. The experiment was conducted at least $3 \mathrm{hr}$ after the final meal and a 30-min rest was taken before the test. Figure 1 illustrates the experimental setup used in the study. The subject holding a mouthpiece in place sat comfortably on a chair. He breathed room air first, and end-tidal $P_{\mathrm{O}_{2}}$ and $P_{\mathrm{CO}_{2}}\left(P_{\mathrm{ET}_{\mathrm{O}_{2}}}\right.$ and $P_{\mathrm{ET}_{\mathrm{CO}}}$, respectively) were continuously monitored by rapid response $\mathrm{O}_{2}$ and $\mathrm{CO}_{2}$ analyzer (San-ei Expired Gas Monitor 1H21). Then, the subject started rebreathing by turning a three-way stopcock to the bag filled by approximatley 10 liters room air. By adjusting the amount of $\mathrm{O}_{2}$ inflow from a cylinder and of $\mathrm{CO}_{2}$ absorbed by a $\mathrm{CO}_{2}$ absorber in the by-pass circuit, $P_{\mathrm{ET}_{\mathrm{O}_{2}} \text { and }}$ $P_{\mathrm{ET}_{\mathrm{CO}_{2}}}$ were set at $100 \mathrm{mmHg}$ and $5 \mathrm{mmHg}$ higher than the control values during room-air breathing, respectively. These $P_{\mathrm{ET}_{\mathrm{O}_{2}}}$ and $\mathrm{PET}_{\mathrm{CO}_{2}}$ values were maintained for at least $3 \mathrm{~min}$ to obtain steady state ventilatory conditions. Then, while maintaining the $P \mathrm{ET}_{\mathrm{CO}_{2}}$ level unchanged, $P_{\mathrm{ET}_{\mathrm{O}_{2}}}$ was progressively lowered by turning off the supply of $\mathrm{O}_{2}$ from the $\mathrm{O}_{2}$ cylinder. The rate of $P_{\mathrm{ET}_{\mathrm{O}_{2}}}$ fall was approximately $10 \mathrm{mmHg} / \mathrm{min}$. When a vigorous ventilatory response appeared in severe

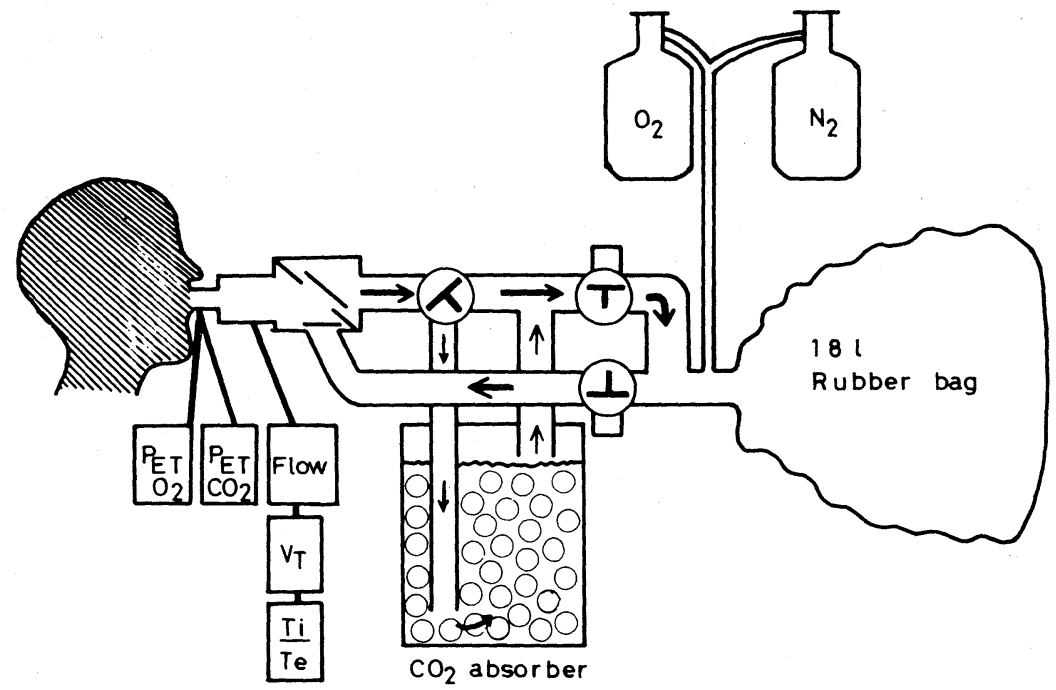

Fig. 1. Experimental setup for the progressive hypoxia test. The subject first breathes room air by turning two three-way stopcocks shown at right. End-tidal $P_{\mathrm{O}_{2}}\left(P_{\mathrm{ET}_{\mathrm{O}_{2}}}\right)$ and $P_{\mathrm{CO}_{2}}\left(P_{\mathrm{ET}_{\mathrm{CO}_{2}}}\right)$ are continuously monitored and recorded. From a hot-wire flow anemometer inserted between mouthpiece and respiraory valve, respiratory flow, integrated tidal volume, inspiratory $(T \mathrm{i})$, and expiratory time $(T \mathrm{e})$ are continuously recorded. After closing the three-way stopcocks to the rebreathing circuits, $P_{\mathrm{ET}_{\mathrm{CO}_{2}}}$ is maintained $5 \mathrm{mmHg}$ higher than the $P_{\mathrm{ET}_{\mathrm{CO}}}$ at room-air breathing by adjusting the three-way stopcock to the $\mathrm{CO}_{2}$ absorber, and $\mathrm{PET}_{\mathrm{O}_{2}}$ is progressively lowered at a rate of about $10 \mathrm{mmHg} / \mathrm{min}$ by cutting off the $\mathrm{O}_{2}$ supply or adding $\mathrm{N}_{2}$ from cylinders. About 10 liters of room air are introduced into an 18 liters rubber bag before rebreathing. 
hypoxia, the addition of $\mathrm{N}_{2}$ into the rebreathing bag was sometimes necessary to keep a continuous $P \mathrm{ET}_{\mathrm{O}_{2}}$ fall. The rebreathing was terminated when $P_{\mathrm{ET}} \mathrm{O}_{2}$ decreased to $40 \mathrm{mmHg}$.

A respiratory flowmeter hot-wire probe (Minato Medical Science Co., Ltd.) inserted between the rebreathing bag and the mouthpiece was used to detect breathby-breath respiratory flow, integrated tidal volume $(V \mathrm{~T})$ and inspiratory $(T \mathrm{i})$ and expiratory time $(T \mathrm{e})$. On a 6-channel pen-recorder (San-ei Recti-Horiz-8K), $P \mathrm{ET}_{\mathrm{O}_{2}}, P_{\mathrm{ET}_{\mathrm{CO}_{2}}}$, respiratory flow, $V \mathrm{~T}, T \mathrm{e}$, and $T \mathrm{i}$ were simultaneously recorded.

Data analysis. The ventilatory response to hypoxia was evaluated using a modified hyperbola equation originally advocated by LLOYD and CUNNINGHAM (1963).

$$
\dot{V}=\dot{V}_{\mathrm{O}}+A /\left(P_{\mathrm{ET}_{\mathrm{O}_{2}}}-C\right),
$$

where $\dot{V}$ is minute ventilation, $\dot{V}_{\mathrm{O}}$ the horizontal asymptote in ventilation for infinite $P_{\mathrm{ET}_{\mathrm{O}_{2}}}, A$ the slope constant of the hyperbola expressing the degree of hypoxic

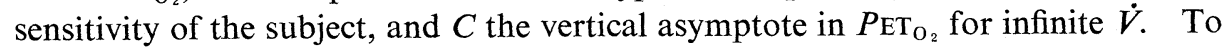
obtain the above three parameters in the equation, $C$ was first determined by a curve-fitting procedure using a microcomputer (Apple II), i.e., seeking the $C$ value which gave the best correlation coefficient between $\dot{V}$ and $1 /\left(P_{\mathrm{ET}_{\mathrm{O}_{2}}}-C\right)$. Then, from the linear regression between $\dot{V}$ and $1 /\left(P_{\mathrm{ET}_{\mathrm{O}_{2}}}-C\right), \dot{V}_{\mathrm{O}}$ and $A$ were determined as the intercept at the ordinate and the slope of the regression line, respectively.

Relationship between $P_{\mathrm{ET}_{\mathrm{O}_{2}}}$ and $\mathrm{Pa}_{\mathrm{O}_{2}}$. In three normal healthy males, blood samples from a catheter inserted in the radial artery were withdrawn six times from each subject during the course of progressive hypoxia. Figure 2 shows that differences between end-tidal and arterial oxygen pressure, $\mathrm{D}(\mathrm{ET}-\mathrm{a}) P_{\mathrm{O}_{2}}$, are

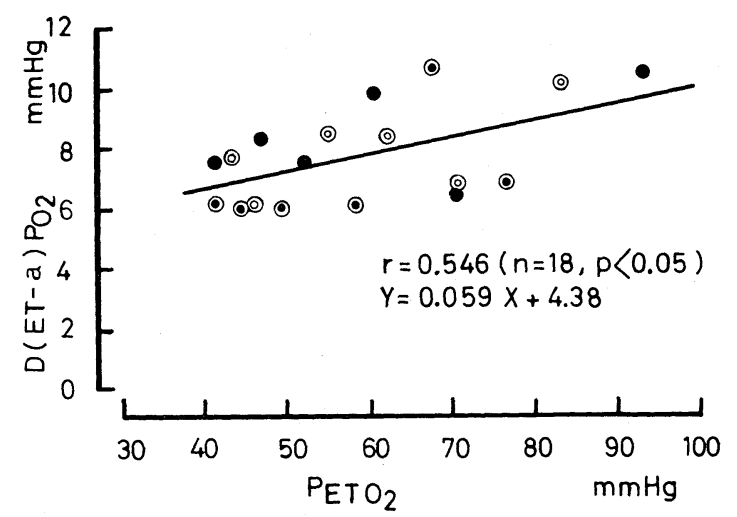

Fig. 2. End-tidal to arterial $P_{\mathrm{O}_{2}}$ difference, $\mathrm{D}(\mathrm{ET}-\mathrm{a}) P_{\mathrm{O}_{2}}$, plotted against end-tidal $P_{\mathrm{O}_{2}}, P_{\mathrm{ET}_{\mathrm{O}_{2}}}$. Six blood samples from the radial artery were obtained for each subject during progressive hypoxia. Different symbols indicate different subjects. A regression line is drawn for the pooled samples. 
well within reasonable values and linearly correlated with $P \mathrm{ET}_{\mathrm{O}_{2}}$. To estimate $P_{\mathrm{O}_{2}}$, the linear relationship with $P_{\mathrm{ET}_{\mathrm{O}_{2}}}$ was ascertained by high correlation coefficient $(r=0.99)$ as follows:

$$
P \mathrm{a}_{\mathrm{O}_{2}}=0.941\left(P_{\mathrm{ET}_{\mathrm{O}_{2}}}-4.65\right) \text {. }
$$

\section{RESULTS}

Figure 3 illustrates examples of progressive hypoxia response in light (I) and

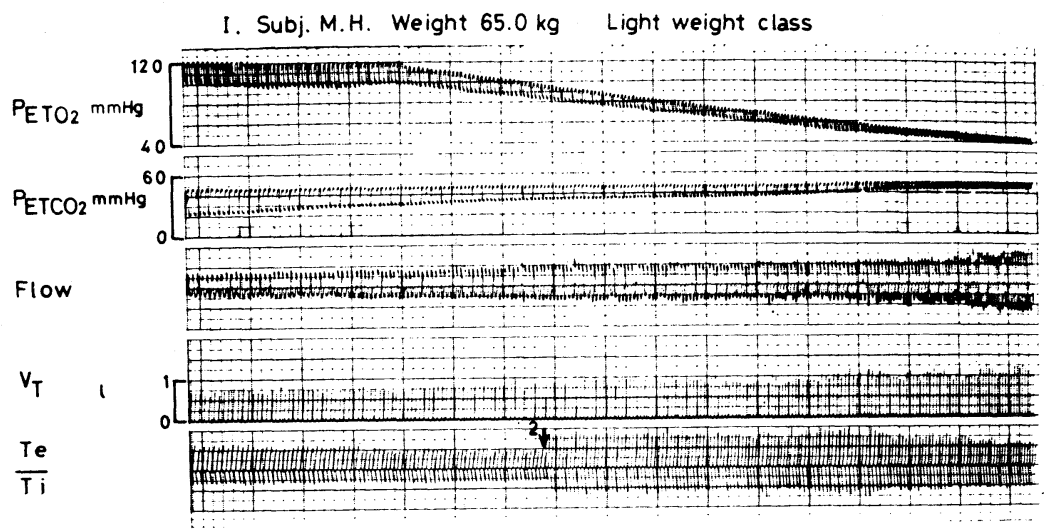

II. Subj. T.N. Weight $125.6 \mathrm{~kg}$ Heavy weight class

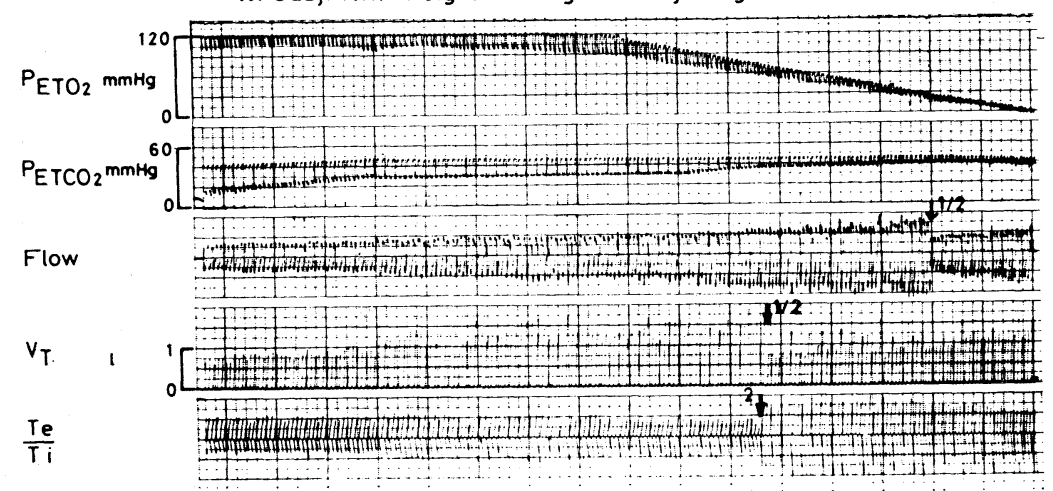

Fig. 3. An example of the experimental record. Upper half: data from lightweight subject

I. Lower half: data from heavyweight subject II with a Röhrer index of 206. The subject first has $P_{\mathrm{ET}_{\mathrm{O}_{2}}}$ made $100 \mathrm{mmHg}$ and $P_{\mathrm{ET}_{\mathrm{CO}}} 5 \mathrm{mmHg}$ higher than in the control; at the arrow indicated at left, progressive hypoxia started. The two arrows shown for subject II at right, indicated that the gain of the recorder for respiratory flow and tidal volume $(V \mathrm{~T})$ was reduced by $50 \%$ because the recordings would otherwise have exceeded the pen limit. On the other hand, the lowest arrow for subject II indicated that the magnitude of $T \mathrm{e}$ and $T \mathrm{i}$ was doubled because of increasing respiraotry frequency. Vigorous hypoxic ventilatory response was seen in subject II. 
heavyweight athletes (II). A vigorous ventilatory response with increasing hypoxia is clearly shown in subject II. As seen in Table 1 , the parameter $A$ 's indicating the slope of the hyperbola response were $295 \pm 264,458 \pm 323$, and $1,155 \pm$ 1,027 liters $\cdot \mathrm{min}^{-1} \cdot \mathrm{mmHg}$ (mean \pm S.D.) in the light and middleweight class (Group I), and A and B of the heavyweight class (Group II A and B), respectively. The differences between Groups II B and I and II B and A were significant $(P<0.001$ and $P<0.05$, respectively).

Such augmentation of hypoxic sensitivity with increasing body weight and Röhrer's index was still seen even after $A$ was recalculated as $A_{\mathrm{N}}$ by using normalized ventilation for $70 \mathrm{~kg}$ body mass using the allometric coefficient $\mathrm{BW}^{0.75}$ (BW: body weight). In Table 1 , the difference in $A_{\mathrm{N}}$ between Groups I and II B

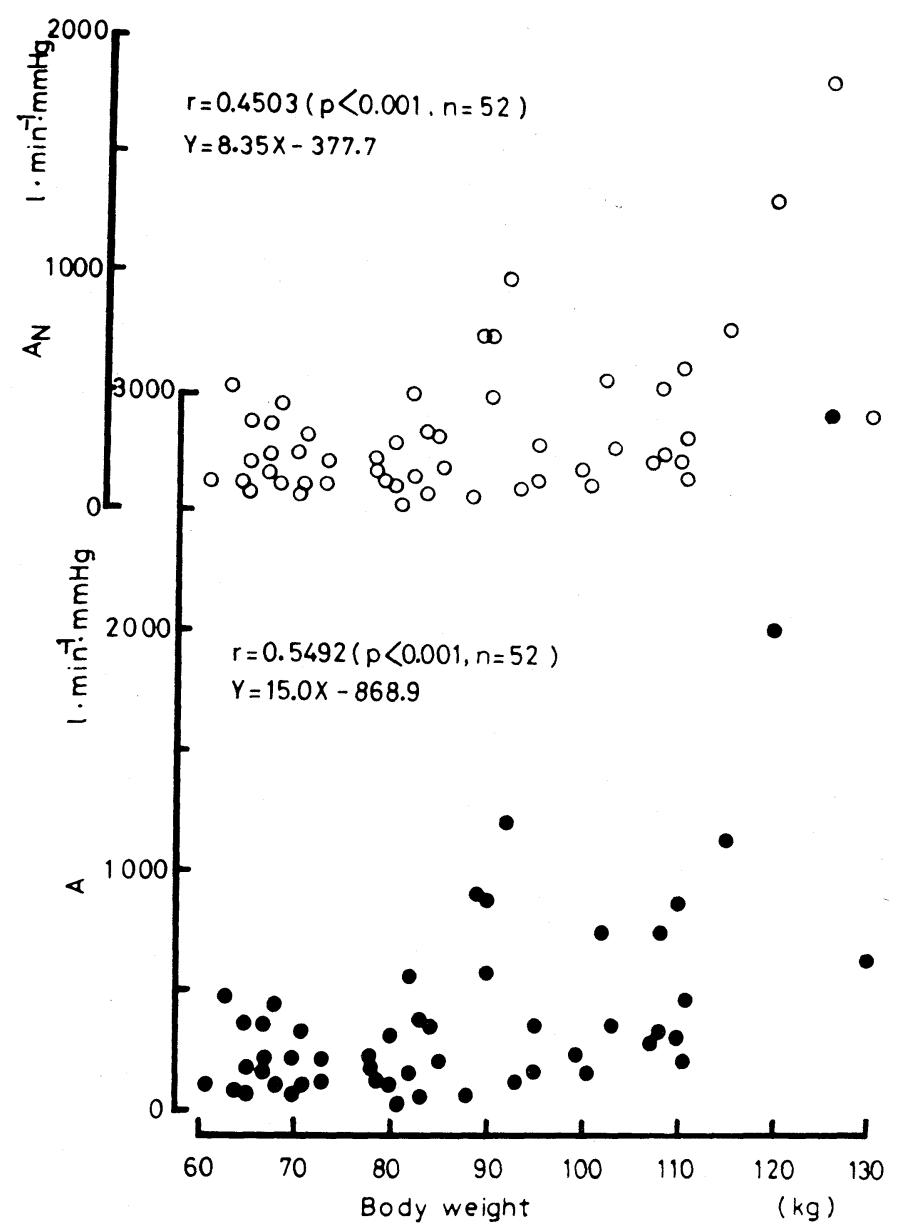

Fig. 4. An index of hypoxic sensitivity, $A$, is plotted against body weight. $A_{\mathrm{N}}$ : recalculated $A$ value after ventilation was normalized for $70 \mathrm{~kg}$ body mass using allometric coefficient. High $A_{\mathrm{N}}$ is still seen in the heavyweight subjects. 


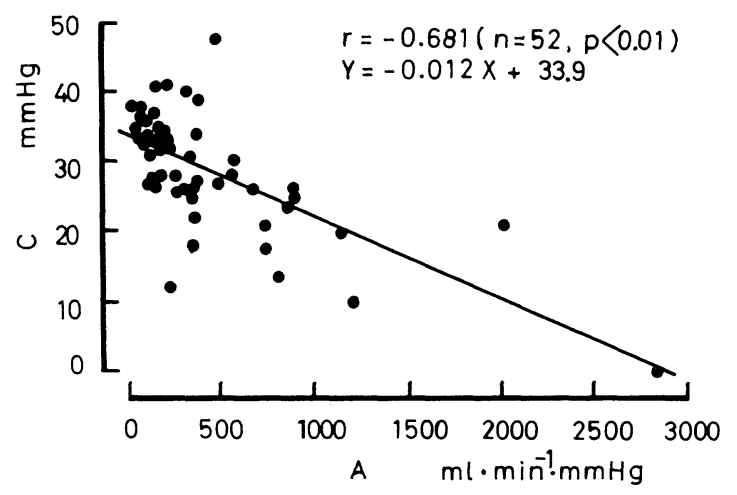

Fig. 5. Vertical asymptote for end-tidal $P_{\mathrm{O}_{2}}, C$, plotted against hypoxic sensitivity index, $A$.

Significant inverse correlation is seen.

is significant $(P<0.01)$, indicating increased hypoxic sensitivity in obesity. $A_{\mathrm{N}}$ and $A$ plotted against body weight are shown in Fig. 4.

Hyperbola analysis for hypoxic ventilatory response was also conducted in terms of the $\mathrm{Pa}_{\mathrm{O}_{2}}$ value which was estimated from the linear relation existing between $\mathrm{Pa}_{\mathrm{O}_{2}}$ and $\mathrm{PET}_{\mathrm{O}_{2}}$ described in the Materials And Methods section. The results are indicated as $A \mathrm{a}, A_{\mathrm{N}}$ a, and $C \mathrm{a}$ in Table 1 . Although the numerical figures were different, the same conclusions as derived from using $P_{\mathrm{ET}_{\mathrm{O}_{2}}}$ values were obtained.

The relationship between $A$ and hyperbolic asymptote for infinite ventilation, $C$, is illustrated in Fig. 5. A significant inverse relationship was seen.

\section{DISCUSSION}

Ventilatory responses to hypoxia as measured by the slope index, $A$, obtained from hyperbola equation were higher with increasing body weight in the Judo athletes. The positive relationships between $A$ and body weight or height have also been observed by WeIL et al. (1971b). However, they admitted that such relationsips disappeared when ventilation was normalized by body size (HIRSHMAN and WeIL, 1976). In our subjects, the difference in $A$ between Group I (light and middleweight class) and Group II A (heavyweight class with Röhrer's index less than 200) became insignificant when ventilation was normalized for $70 \mathrm{~kg}$ body mass. However, a significant difference in $A$ still existed between Group I and Group II B (heavyweight class with Röhrer's index higher than 200) after such normalization of ventilation. Moreover, the positive correlation seen between $A$ and body height disappeared when $A$ was recalculated on the basis of normalized ventilation in our subjects. These results indicated that body weight plus obesity may have contributed to the increase of hypoxic sensitibity, $A$.

In addition to the obesity factor described above, numerous other factors 
have been reported to affect hypoxic sensitivity: altitude exposure (MILLEDGE and LAHIRI, 1967; WeIL et al., 1971a), athleticism (BYRNE-QUINN et al., 1971; MARTin et al., 1978), hyperthermia (NATAlino, 1977), mixed venous $P_{\mathrm{CO}_{2}}$ level (REBUCK and Woodley, 1975), malnutrition (DAeKel, 1976), aging (KronenberG and Drage, 1973), familial or genetic factor (Collins et al., 1978; SCOGGIN, 1978; KAWAKAMI et al., 1981a; KAWAKAMI et al., 1981b), congenital cyanotic heart disease (SøRENSEN and Severinghaus, 1968; Blesa et al., 1977), various drugs, anesthesia or sedation (HIRSHMAN et al., 1975a; HirSHMAN et al., 1975b; YACOUB et al., 1976; HirShman et al., 1977; KNILL and Gelb, 1978; KNILl et al., 1978; LAKSHMINARAYAN et al., 1978; SANDERS et al., 1980), and alveolar hypoventilation syndromes (Shannon and Kelly, 1977; BRAdLey et al., 1979; SCHIFFMAN et al., 1980; Berman et al., 1981; Hunt et al., 1981). None of the above factors, however, seems to satisfactorily explain the results obtained in the present study.

One of the possible reasons why our obese Judo athletes exhibited higher ventilatory activity in hypoxia is inferred to be their strong physical activity with high metabolism in everyday training. ZWILLICH et al. (1975b) observed that thyroid hormone replacement therapy augmented the $A$ value significantly in myxedema and hypothyroidism. On the other hand, Stockley and Bishop (1977) detected augmented peripheral chemosensitivity using oxygen breath testing in 7 thyrotoxicosis patients. LeVINE and HuCKabeE (1975) also demonstrated in dogs that drug-induced hypermetabolism caused hyperventilation which seemed to arise in the peripheral tissues other than the peripheral or central chemoreceptors. In all probability, the metabolic activity of our subjects may be higher than in sedentary obese patients who exhibit hypoventilation and decreased hypoxic and/or hypercapnic sensitivity. Whether or not the degree of metabolic activity definitely explains our results needs further clarification.

It must be mentioned here why we examined hypoxic response with the $P_{\mathrm{ET}_{\mathrm{CO}_{2}}} 5 \mathrm{mmHg}$ higher than the control level. Generally, hypoxic stimulation is very weak until $P_{\mathrm{ET}_{\mathrm{O}_{2}}}$ decreases to about $60 \mathrm{mmHg}$. Therefore, if ventilatory response is obtained at the resting $P_{\mathrm{ET}_{\mathrm{CO}}}$ level, its magnitude is easily changeable up to about $P_{\mathrm{ET}_{\mathrm{O}_{2}}} 60 \mathrm{mmHg}$. However, when $P_{\mathrm{ET}_{\mathrm{CO}_{2}}}$ is increased by several $\mathrm{mmHg}$ as in the present experiment, stable ventilatory volume can be assessed even in light and moderate hypoxia, and thus consistent hypoxic response curves are assured. REBUCK et al. (1973) also conducted a progressive hypoxia test with $P_{\mathrm{ET}_{\mathrm{CO}}}$ kept at a mixed venous $P_{\mathrm{CO}_{2}}$ level which was probably about the same as the $P_{\mathrm{ET}_{\mathrm{CO}}}$ value used in this study.

Finally, the magnitude of $C$, the vertical asymptote for $P_{\mathrm{ET}_{\mathrm{O}_{2}}}$ in the hyperbola equation, must be considered. WeIL et al. (1971b) have been conducting an extensive study using the hyperbola equation, and they put a constant $C$ value of $32 \mathrm{mmHg}$ into this equation. The reason why they used a fixed $C$ is not clear to us. In fact, as shown in Table 1 and Fig. 5, there was some scatter in this value. Such a variation in the $C$ level has been reported by MiLledge and LAHIRI (1967) 
on comparing hypoxic response between lowlanders and sherpa highlanders. Even in Fig. 6 of the original paper of WeIL et al. (1971b), there seems to be an increasing $C$ level with an increasing isocapnic level in the hypoxia test. As shown in Fig. 5, we found a positive inverse relationship between $C$ and $A$ values. This result indicated that the hypoxic threshold level for infinite ventilation decreased with increasing $A$.

\section{REFERENCES}

Berman, T. B., Bartlett, M., Westgate, H. D., Steiner, K. R., and Kronenberg, R. S. (1981) Attenuated responses to $\mathrm{CO}_{2}$ and hypoxia in parents of threatened sudden infant death syndrome infants. Chest, 79: 536-539.

Blesa, M. I., Lahiri, S., Rashkind, W. J., and Fishman, A. P. (1977) Normalization of the blunted ventilatory response to acute hypoxia in congenital cyanotic heart disease. $N$. Engl. J. Med., 296: 237-241.

Bradley, C. A., Fleetham, J. A., and Anthonisen, N. R. (1979) Ventilatory control in patients with hypoxemia due to obstructive lung disease. Am. Rev. Respir. Dis., 120: 21-30.

Burwell, C. S., Robin, E. D., Whaley, R. D., and Bickelmann, B. G. (1956) Extreme obesity associated with alveolar hypoventilation-A Pickwickian syndrome. Am. J. Med., 21: 811818.

Byrne-Quinn, E., Weil, J. V., Sodal, I. E., Filley, G. F., and Grover, R. F. (1971) Ventilatory control in the athletes. J. Appl. Physiol., 30: 91-98.

Collins, D. D., Scoggin, C. H., Zwillich, C. W., and Weil, J. V. (1978) Heredity aspects of decreased hypoxic response. J. Clin. Invest., 70: 105-110.

Cullen, J. H. and Formel, D. F. (1962) The respiratory defects in extreme obesity. Am. J. Med., 32: 525-531.

Daekel, R. C., Zwillich, C. W., Scoggin, C. H., Kryger, M., and Weil, J. V. (1976) Clinical semi-starvation. Depression of hypoxic ventilatory response. N. Engl. J. Med., 295: 358361.

Garay, S. M., Rapoport, D., Sorkin, B., Epstein, H., Feinberg, I., and Goldring, R. M. (1981) Regulation of ventilation in the obstructive sleep apnea syndrome. Am. Rev. Respir. Dis., 124: 451-157.

Hirshman, C. A., McCullough, R. E., Cohen, P. J., and Weil, J. V. (1975a) Effect of pentobarbitone on hypoxic ventilatory drive in man. Br. J. Anaesth., 47: 963-968.

Hirshman, C. A., MCCullough, R. E., Cohen, P. J., and Weil, J. V. (1975b) Hypoxic ventilatory drive in dogs during thiopental, ketamine, or pentobarbital anesthesia. Anesthesiology, 43: 628-634.

Hirshman, C. A., McCullough, R. E., Cohen, P. J., and Weil, J. V. (1977) Depression of hypoxic ventilatory response by halothane, enflurane, and isoflurane in dogs. Br.J. Anaesth., 49: 957-963.

Hirshman, C. A. and Weil, J. V. (1976) Letters to the editor. Hypoxic and hypercapnic ventilatory drives in man. J. Appl. Physiol., 40: 1012.

Hunt, C. E., McCulloch, K., and Broullette, R. T. (1981) Diminished hypoxic ventilatory responses in near-miss sudden infant death syndrome. J. Appl. Physiol.: Respir. Environ. Exercise Physiol., 50: 1313-1317.

Kawakami, Y., Irie, T., Kishi, F., Asanuma, Y., Shida, A., Yoshikawa, T., Kamishima, K., Hasegawa, H., and MuraO, M. (1981a) Familial aggregation of abnormal ventilatory control and pulmonary function in chronic obstructive pulmonary disease. Eur. J. Respir. Dis., 62: 56-64. 
Kawakami, Y., Yoshikawa, T., Shida, A., and Asanuma, Y. (1981b) Relationship between hypoxic and hypercapnic ventilatory response in man. Jpn. J. Physiol., 31: 357-368.

KNILl, R. L., Bright, S., and MANnimen, P. (1978) Hypoxic ventilatory responses during thiopentone sedation and anesthesia in man. Can. Anaesth. Soc. J., 25: 366-372.

KNILL, R. L. and GeLB, R. W. (1978) Ventilatory responses to hypoxia and hypercapnia during halothane sedation and anesthesia in man. Anesthesiology, 49: 244-251.

Kronenberg, R. S. and Drage, C. W. (1973) Attenuation of the ventilatory and heart rate responses to hypoxia and hypercapnia with aging in normal men. J. Clin. Invest., 52: 18121819.

Kronenberg, R., Drage, C. W., and Stevenson, J. E. (1977) Acute respiratory failure and obesity with normal ventilatory responses to carbon dioxide and absent hypoxic ventilatory drive. Am. J. Med., 62: 772-776.

Kronenberg, R., Gabel, R. A., and Severinghaus, J. W. (1975) Normal chemoreceptor function in obesity before and after ileal by pass surgery to force weight reduction. Am.J.Med., 59: 349-353.

Lakshminarayan, S., Sahn, S. A., and Weil, J. V. (1978) Effect of aminophyllin on ventilatory response in normal man. Am. Rev. Respir. Dis., 117: 33-38.

LeVine, S. and Huckabee, W. E. (1975) Ventilatory response to drug induced hypermetabolism. J. Appl. Physiol., 38: 827-833.

Lloyd, B. B. and CunNinghaM, D. J. C. (1963) A quantitative approach to the regulation of human respiration. In: The Regulation of Human Respiration, ed. by CunNINGHAM, D. J. C. and Lloyd, B. B. Blackwell Sci. Publ., Oxford, pp. 331-349.

Lourenço, R. V. (1969) Diaphragm activity in obesity. J. Clin. Invest., 48: 1609-1614.

Martin, B. J., Weil, J. V., Sparks, K. E., McCullough, R. E., and Grover, R. F. (1978) Exercise ventilation correlates positively with ventilatory chemoresponsiveness. J. Appl. Physiol.: Respir. Environ. Exercise Physiol., 45: 557-564.

Milledge, J. S. and LAHIRI, S. (1967) Respiratory control in lowlanders and sherpa highlanders at altitude. Respir. Physiol., 2: 310-322.

Natalino, M. R., Zwillich, C. W., and Weil, J. V. (1977) Effects of hyperthermia on hypoxic ventilatory response in normal man. J. Lab. Clin. Med., 89: 564-572.

Rebuck, A. S., Kanagalee, M., Pengelly, L. D., and Campbell, J. M. (1973) Correlation of ventilatory responses to hypoxia and hypercapnia. J. Appl. Physiol., 35: 173-177.

Rebuck, A. S. and Woodley, W. E. (1975) Ventilatory effects of hypoxia and their dependence on $P_{\mathrm{CO}_{2}}$. J. Appl. Physiol., 38: 16-19.

Sanders, J. S., Berman, T. M., Bartlett, M. M., and KronenberG, R. S. (1980) Increased hypoxic ventilatory drive due to administration of aminophylline in normal men. Chest, 78: 279-282.

Schiffman, P. L., Westlake, R. E., Santiago, T. V., and Edelman, N. H. (1980) Ventilatory control in parents of victims of sudden-infant-death syndrome. N. Engl. J. Med., 302: 486-491.

Scoggin, C. H., Doekel, R. D., Kryger, M. H., Zwillich, C. W., and WeIL, J. V. (1978) Familial aspects of decreased hypoxic drive in endurance athletes. J. Appl. Physiol.: Respir. Environ. Exercise Physiol., 44: 464-468.

Shannon, D. C. and Kelly, D. (1977) Impaired regulation of alveolar ventilation and the sudden infant death syndrome. Science, 197: 367-368.

Sørensen, S. C. and Severinghaus, J. W. (1968) Respiratory insensitivity to acute hypoxia persisting after correction of tetralogy of Fallot. J. Appl. Physiol., 25: 221-223.

Stockley, R. A. and Bishop, J. M. (1977) Effect of thyrotoxicosis on the reflex hypoxic respiratory drive. Clin. Sci. Mol. Med., 53: 93-100.

Weil, J. V., Byrne-Quinn, E., Sodal, I. E., Filley, G. F., and Grover, R. F. (1971a) Acquired 
attenuation of chemoreceptor function in chronically hypoxic man at high altitude. J. Clin. Invest., 50: 186-195.

Weil, J. V., Byrne-Quinn, E., Sodal, I. E., Friesen, W. D., Underhill, B., Filley, G. F., and Grover, R. F. (1971b) Hypoxic ventilatory drive in normal man. J. Clin. Invest., 49: 1061-1072.

YaCoub, O., Doell, D., Kryger, M. H., and Anthonisem, N. R. (1976) Depression of hypoxic ventilatory response by nitrous oxide. Anesthesiology, 45: 385-389.

Zwillich, C. W., Sutton, F. S., Pierson, D. J., Creagh, E. M., and Weil, J. V. (1975a) Decreased hypoxic ventilatory drive in the obesity-hypoventilation syndrome. Am. J. Med., 59: 343-348.

Zwillich, C. W., Piersen, D. J., Hofeldt, F. D., Lufkin, E. G., and Weil, J. V. (1975b) Ventilatory control in myxedema and hypothyroidism. N. Engl. J. Med., 292: 662-665. 